\title{
$\mathrm{N}-$ Screen과 클라우드 컴퓨팅 패러다임에서의 지속가능한 UX 생태계 구축에 대한 연구
}

김 성 우

$\mathrm{KT}$ 종합기술원 중앙연구소

\section{Building a Sustainable UX Ecosystem under N-Screen and Cloud Computing Paradigm}

\author{
Sung Woo Kim
}

KT, CTO, Centralized R\&D Laboratory, 17 Woomyeon-dong, Seocho-gu, Seoul, Korea, 137-792

\begin{abstract}
This paper discusses the next direction for user experience design to keep pace with an ongoing IT paradigm shift, particularly focused on UX standardization activity contributing to reinforcement of brand power and customer loyalty. The paper introduces a model that identifies four levels of UX standardization and a key concept called "sustainable UX ecosystem" as its top level. It argues that in the new IT paradigm the fourth level of UX standardization, the sustainable UX ecosystem, is the next direction user experience must head towards.
\end{abstract}

Keywords: User Experience, Ecosystem, N-Screen, Cloud Computing, UX Design

\section{1. 연구배경}

\section{1 글로벌 IT 패러다임의 변화}

IT 산업계는 지난 10 년 간의 성장과 변화의 누적된 결과 로 바야흐로 급격한 패러다임 변화(paradigm shift)를 맞 이하고 있다. 2004년 등장한 Web 2.0 (Oreilly weblink 참 조), 2007년 모바일 업계에 데뷔하여 진정한 모바일 인터 넷의 체험을 가져온 아이폰과 그 뒤를 이은 스마트폰의 유 행, 새로운 가치 사슬과 이익분배라는 강력한 비즈니스 모 델을 앞세워 소프트웨어 업계의 새로운 블루오션으로 급부 상한 앱스토어, 유무선 인터넷 환경을 기반으로 차세대 IT 인프라로 떠오르는 클라우드 컴퓨팅, 컨텐츠 판매의 극대화 를 위해 등장하여 이제는 IT 생활 환경의 근본적인 변화를
가져온 N-Screen(AT\&T weblink 참조), 제조업체와 통 신사 등 기존의 IT 가치 사슬 안의 권력 구도를 단번에 뒤 집어 엎으면서 새로운 강자로 떠오른 플랫폼 오너(platform owner)는 모두 IT 산업계가 기존과는 다른 새로운 양상으 로 흘러가고 있음을 잘 보여주는 현상이다.

IT 산업계에 두드러지게 나타나는 핵심 양상 몇 개를 기반 기술(infrastructure), 비즈니스 모델 및 사용자 행동 (user behavior) 관점에서 나열하면 아래와 같다.

- 진정한 모바일 인터넷 환경

-Connected Device, M2M, Emerging Device

- 클라우드 컴퓨팅 (Cloud Computing)

- $\mathrm{N}-\mathrm{Screen}$ 환경

- 개방화

교신저자: 김성우

주소: 137-792 서울시 서초구 우면동 17번지, 전화: 010-9888-6052, E-mail: caerang@gmail.com 
- 적극적 주체로서의 고객

•소셜 네트워킹 (Social Networking)

이 중에서도 특히 주목 받는 변화는 클라우드 컴퓨팅 (Cusumano, 2010) 과 N-Screen이다. 이들은 인터넷 연결 성(connectivity), 소프트웨어, 하드웨어, 컨텐츠와 서비스 가 모두 하나로 집결되는 총체적인 IT 환경을 잘 대변하기 때문이다. 본 연구 역시 클라우드 컴퓨팅과 N-Screen으로 대변되는 새로운 IT 패러다임에 초점을 맞추어 UX 디자인 의 차세대 방향에 대해서 다루고자 한다.

\subsection{IT 패러다임 변화에 따른 UX 디자인의 차세대 방향}

앞서 소개한 IT계의 급속한 패러다임 변화 속에서 IT에 서의 UX 역시 단위 제품/서비스별 사용성이나 GUI 디자인 과 같은 전통적인 UI 사안을 너머선 다음 차원의 UX 디자 인 방향을 모색해야 하는 시점에 이르렀다.

지난 10년간 IT 산업계의 UX 트렌드를 살펴 보면 90년 대 말과 2000년대 초반에 걸쳐 단위별 제품 또는 서비스의 사용성 향상과 좋은 UI 디자인 프렉티스(design practice) 가 주된 관심사 이었다면 2000년대 중반 이후로 이런 프 렉티스를 기반으로 하여 GUI 표준화에 대한 관심이 많이 일어났다(Sony XMB weblink 및 전자신문 2005년 4월 25일자 기사 참조). 그 이후 지금까지 상당수 기업에서 UX 표준화에 힘을 쏟고 있다.

$\mathrm{UX}$ 표준화는 특히 복수 개의 제품/서비스 라인을 가진 기업에서의 주요 UX 사안이다. BI(Brand Identity) 와 마찬 가지로 표준화된 UX는 기업의 브랜드 파워 강화에 큰 영향 력을 행사하기 때문이다. 표준화의 이런 속성은 기업 내 UX 조직이 그들의 R\&R(Roles \& Responsibilities) 와 가치 제 언(value proposition)을 효과적으로 가시화할 수 있는 전 략 포인트로 부각되어 브랜딩에 초점을 맞춘 UI 표준화가 UX계에서 매우 중요한 관심사가 되었다(Markus, A., 2004; Sampson, F., 2005).

그렇다면 표준화와 같은 브랜딩을 위한 UX 디자인 활동 은 앞서 소개된 IT 패러다임 변화 속에서 어떤 모습으로 진화할 것인가? 확실한 것은 IT의 인프라와 비즈니스 모델 이 근본적으로 바뀌는 지금 기존의 전개 방식 그대로 계속 갈 수는 없다는 것이다. 새로운 변화에 맞게 새로운 표준화 전개 방식에 대한 담론과 연구가 필요한 시점이 되었다. 본 논문에서는 N-Screen과 클라우드 컴퓨팅 환경으로 대변 되는 글로벌 IT 패러다임 변화에 맞춰 브랜딩에 공헌하는 $\mathrm{UX}$ 표준화 전략이 취해야 할 다음 방향과 전개 방식에 대 해 짚어본다.

\section{UX 표준화의 4단계 모델}

복수 개의 제품/서비스(이하 가급적 서비스로 통칭)를 제 공하는 기업에서 서비스 간의 UX 표준화(cross-service UX standardization)는 기업 내 UX 전문가들의 주된 업무 이다. 일관성 있는 상호작용의 경험(interaction experience) 을 통해 기업의 브랜드 파워 강화와 소비자의 고객 고착화 (customer lock-in)에 기여할 수 있기 때문이다.

다만 아직까지 많은 기업에서 UX 표준화가 GUI에서의 비주얼 스타일(visual style) 표준화에 국한되어 있는 경우 가 다반사이다. 즉, 컬러, 배치(layout), 아이콘, 사운드와 같 이 주로 시청각적 요소의 규격화에 한정되어 있다. UX 표 준화는 GUI 스타일의 규격화 이상의 사안이며 특히 UI 너 머 UX 관점으로 확대해 보면 그림 1 과 같은 4 단계로 세분 화된다.

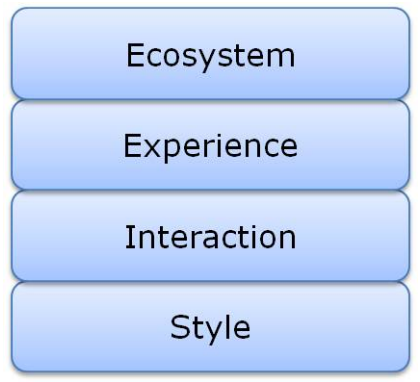

그림 1. UX 표준화 4단계

1 단계는 시청각적 UI 요소의 규격화 단계로 가장 기초적 이고 하위 수준의 표준화이다. 앞서 말한 GUI 표준화는 바 로 이 단계에 해당한다. 또 다른 예로 사운드 표준화를 들 수 있다.

2단계는 UI 중에서 인터랙션 규칙과 제도(interaction rules \& policies) 에 해당하는 사안에 대한 표준화이다. 특 히 1 단계가 주로 시각적 요소를 다룬다는 점에서 2 단계에 서는 소위 비가시적 인터랙션 요소(non-visual interaction elements)들이 가장 대표적인 표준화 대상이 된다. 이를테 면 서비스간 내비게이션 방식의 통일화나 일관성 있는 메뉴 구조와 같은 IA (Information Architecture)의 규격화가 2 단계의 표준화 작업을 통해 나오는 산출물이다.

1,2 단계는 전통적인 UI와 사용성 (usability) 분야에서 오랫동안 다루어왔던 표준화 사안이기도 하다. 대부분의 기 업에서의 UX 표준화란 1,2 단계의 표준화를 지칭하며 앞서 도 말했듯 아직까지 1 단계 표준화에 머물러 있는 기업도 상 당수 있다. 1 단계에서 조금 더 진척을 보인 기업들이라 하더 라도 많은 경우 1 단계 표준화 가이드라인에 2 단계에 해당 
하는 내용을 필요에 따라 여기저기 체계 없이 정리를 해 둔 정도이다(1.5단계 수준).

3단계부터가 전통적인 UI를 뛰어넘어 경험의 문제를 다 루는 단계이다. 현재까지의 연구를 통해 볼 때 3단계는 (1) 인터랙션 경험(interaction experience)에 해당하는 경험 요소 중 전통적인 UI의 표준화를 다루는 1,2 단계에서 커버 되지 않는 인터랙션 경험 요소와 (2) 인터랙션 경험 요소 이상의 사용자 경험 요소들을 표준화 이슈로 다루는 단계인 것이다. 3단계의 관점에서 UX는 "전통적 UI 이상의 무엇" 이며 전통적 UI와 사용성을 상징하는 인터랙션 경험 요소는 $\mathrm{UX}$ 를 이루는 여러 경험 요소의 하나이다.

3 단계에서 표준화 대상이 되는 요소들은 아직까지 명확 하게 규정되지 않았다. 몇몇 기업에서 자신들의 사업 모델과 제공하는 서비스의 성격에 따라 나름대로의 기준을 정하여 그에 맞는 체험의 표준화를 시도하고 있는 정도이다. 3 단계 에서 다룰만한 표준화 이슈의 예로 아래와 같은 사안들을 생각해 볼 수 있다

- TV 제조업체의 예: 4방향 navi-key 리모콘을 사용하는 보급형 TV와 닌텐도 Wii와 같은 포인터 방식(pointer input device) 기반의 고급형 TV의 UI에서 어떻게 하면 서로 동일한 $\mathrm{UX}$ 적 일관성을 제공하여 전체적으로 하나의 $\mathrm{TV}$ 브랜드라는 인식을 소비자에게 줄 수 있는가?

- 유무선 통신 업체의 예: 휴대폰에 들어가 있는 컨택 정보, 영상 통화가 가능한 IPTV에 수록된 컨택 정보 및 VoIP 디바이스에 수록된 컨택 정보를 어떻게 실시간 동기화 시 켜 줄 것인가?

- 경영학의 CEM(Customer Experience Management) 분 야에서 다루는 체험단서(experience cue)에 해당하는 사 안들. 즉 소비자 체험(CX - Customer Experience) 관점 의 UX 요소들(Shaw, C. and Ivens. J., 2004; Meyer, C., Schwager, A., 2008)

3단계의 표준화 대상이 아직 명확하지 않은 것은 UI를 너머선 UX의 표준화된 산업 정의(industry standard definition) 자체가 아직 명확하게 규정되지 않았기 때문이 기도 하다. 지난 10 년간 UX 커뮤니티는 HCI, GUI, 인터랙 션 디자인, IA, 사용성과 같은 전통적인 UI와 UX를 동일시 하는 부류와 UI와 UX의 차별화(주로 UX가 UI보다 상위 개념으로 보며)를 시도하는 부류들 간의 대립과 갈등 속에 서 다소 혼탁한 상황을 거쳐왔고 지금도 해소되지 않는 상 태이다(CHI 2008 SIG 참조).

문제는 1 장에서 소개한 IT 패러다임이 3 단계 표준화를 위한 UX의 안정적인 정의와 규정(identification)을 기다리 지 않고 급격하게 변화하며 이미 4 단계 급의 UX 표준화를
요구하고 있다는 것이다. 이러한 현상은 특히 애플이나 구글 같이 IT 가치 사슬의 최고 위치로 단기간에 수직상승한 플 랫폼 오너(platform owner) 들에서 종종 보인다. 이런 기업 들은 자신들이 제공하는 여러 서비스의 경험들에 대해 이런 저런 자체적 기준을 통한 통일성/일관성을 제공하는 3 단계 표준화를 넘어 그들이 제공하는 체험들을 통합 구축하고 사 용자들이 그 체험 세계 속에 장기간 내지 영구히 거주하여 살아 갈 수 있는 생태 환경을 조성하는 전략을 구사하고 있다.

\section{3. 지속가능한 UX 생태계 (Sustainable UX Ecosystem)의 정의}

$\mathrm{UX}$ 생태계란 사용자에게 제공되는 서비스들의 UX가 상 호간에 유기적인 연결을 통해 사용자에게 심리스(seamless) 하고 통합적 (unified)인 생태 환경으로 제공되는 것을 말한 다. 사용자들은 그 생태 환경 속에서 각종 서비스, 다른 사 용자들 및 기타 요소들과 공생 관계를 이루면서 장기간 내 지 영구히 거주하게 된다.

UX 생태계의 개념은 그 뿌리를 생물학의 생태계에 두고 있다. 생물학의 생태계를 간단히 살펴보면 다음과 같다.

- 상호간의 관계를 지닌 생물과 무기적 환경을 하나로 통합 하는 개념

- 상호작용하는 유기체들과 또 그들에게 영향을 주고 영향 을 받는 주변의 무생물의 환경을 하나로 칭함

- 생물공동체와 무기적 환경과의 사이에는 물질교대와 에너 지교대가 이루어짐

생물학적 생태계의 정의에서 얻을 수 있는 핵심 개념들은 (1) 환경을 구성하는 모든 요소를 전체의 하나로 묶어 본다 는 점 (2) 요소들이 유기적인 공생 관계를 가진다는 점 (3) 생물체가 그 생태계 안의 한 구성원으로서 지속적으로 그 세계 안에 거주한다는 점이다. 이러한 점에 착안하여 본 연 구에서 주창하는 UX 생태계는 그림 2 와 같은 기존의 UX 사상에 새로운 변화를 가져온다.

\section{사용자(user)에서 거주자(inhabitant)로}

기존의 UI는 UCD(User-centered Design)에서도 알 수 있듯 사용자(user)란 말을 중시한다. 경영학의 $\mathrm{CEM}$ (Customer Experience Management)에서 고객(customer 또는 client)이란 표현을 쓰는 것과 대비된다. 표준화 1 3 단계에서는 고객이란 서비스 단위 별로 "사용하는 사람"이 




그림 2. UX 생태계에서 바뀌는 개념

고 이런 사용자의 주된 행동 성향은 "사용(use)"이다. 4단계 표준화인 UX 생태계에서는 고객을 사용자(user)보다는 거 주자(inhabitant)로 정의한다.

"사용하다" 가 "살아가다" 로

고객을 사용자 대신 거주자로 보게 되면 고객의 주된 행동 역시 "사용(use)"이 아니라 생태계에 "거주(settle down의 의미를 내포한 inhabit)"하는 것이 된다. 즉, "사용자가 서비 스를 사용 (users use services)"하는 관점에서 "거주자가 서비스를 살아가는(inhabitants live services)" 관점으로 사상의 근본적인 변화를 불러온다.

고객은 거주자로서 서비스가 제공하는 세계에 장기간 내 지 영구적으로 서식을 하게 되고, 서비스는 거주자가 자신의 생존과 나아가 품격 있는 라이프스타일의 유지를 위해 지 속적으로 상호작용하는 필수불가결한 대상이 되며, "서비스 를 사용한다(use)"는 거주자와 서비스간의 지속적이고 끊 임 없는 상호작용을 바탕으로 거주자가 "서비스를 살아가는 (live)" 것이 된다. 이는 생물학적 생태계에서 유기체(=고 객)가 생명유지 활동을 위해 끓임없이 무기체 (=서비스)와 물질교대나 에너지교대와 같은 상호작용을 하는 것과 유사 하다.

\section{지속가능성}

생물학적 생태계에서도 그러하듯 UX 생태계에서도 지속 가능성(sustainability)은 생태계의 존립에 매우 중요한 조 건이다. 앞서 설명한 거주자가 서비스를 살아가는 개념에서 거주자와 서비스가 지속적으로 상호작용하는 것이 거주의 기본 패턴이 된다. 즉 고객이 서비스와 24시간, 7 일, 365 일 내내 소통하고 호흡할 수 있도록 생태계 환경이 조성되어야 한다.

지속가능성은 건강한 생태계의 조성을 지향한다는 의미를 가지고 있다. 생태계의 건강성을 유지하기 위해서는 생태계 의 균형 (balance)을 깨는 부정적인 요소를 제거하고 긍정적 인 요소를 잘 관리하여 지속적으로 유지\&발전하는 것이다.
이는 UX 디자인의 체계적인 관리와 경영으로 연결된다(정 경원, 2006; 조기원, 2007).

나아가 지속가능성은 UX 생태계의 건강성뿐만 아니라 $\mathrm{UX}$ 를 통해 우리가 실제로 살고 있는 물리적 세계의 건강성 에 기여한다는 철학도 내포하는 것으로 UX 생태계를 구축 하고 운영하는 기업의 사회 책임 (CSR - Corporate Social Responsibility)에 직결된다. 지구 온난화 같은 환경 문제, 공정 거래(fair trade), 인간 가치 (human value) 증진에 대 한 디자인 커뮤니티의 적극적 참여는 디자이너의 기본 의무 로 UX 디자인도 예외일 수 없다. 따라서 기업의 UX 표준 화 활동에서 전통적으로 지향하는 사용성, 효율성, 일관성 이외에도 기업의 사회책임성과 같은 새로운 목표가 추가되 어야 한다. 4 단계 표준화인 UX 생태계 구축에서의 지속가능 성이 바로 이런 부분을 커버하는 것이다. 이를테면 지구 환 경을 고려하는 sustainable UX(Pierece, Roedl, 2008)가 이런 지속가능성의 대표적인 디자인 사안이 된다. CSR이 기 업의 브랜드 이미지에 미치는 영향은 이미 입증되었고 수많 은 기업들이 CSR 관리 체제를 구축하기 위해 투자를 하고 있다.

요약하자면 거주자로서의 고객과 거주자의 삶에 필수불가 결한 요소로서의 서비스가 끊임없이 상호작용하면서 지속적 으로 고객이 서비스를 살도록 생태적 환경을 조성하고 이를 통해 기업 브랜드 강화에 UX 차원에서 기여하는 것이 4 단 계 표준화인 지속가능한 UX 생태계(sustainable UX ecosystem)인 것이다.

\section{4. 지속가능한 UX 생태계의 중요성}

앞서 설명했듯 UX 표준화는 기업의 브랜드 파워 강화와 고객 충성도의 향상에 그 목표를 두고 있다. 이러한 목표는 가장 기초적 수준인 1 단계 시청각적 요소의 표준화에서부터 시작되며 단계가 올라갈수록 UX 측면에서 보다 고도화된 브랜드 체험을 제공하게 된다. 즉 표준화의 단계를 높일수 록 UX를 통해 브랜드 파워 강화와 소비자 충성도의 향상에 보다 기여하는 것으로 가장 상위 단계인 지속가능한 UX 생 태계를 이룩하는 것은 UX 측면에서 브랜드 파워 강화 및 소비자 충성도 향상에 가장 높게 기여하게 되는 것이다.

고객이 단순히 "사용하는 사람"이 아니라 "영구정착한 사 람"으로서 UX 생태계에 살게 되면 고객은 그 생태계를 제 공하는 기업의 서비스에 평생 고객이 되는데 이는 자연스럽 게 소비자 충성도의 극대화로 이어진다. 표준화 4 단계는 UX 생태계에서 고객 고착화(customer lock-in)를 구축할 수 있는 가장 확실한 방법이다. 마치 생물학적 생태계에서 어떤 
한 생물체가 어떤 한 생태계에서 생존에 적절한 자신의 위치 를 찾게 되면 거기에 한 구성원이 되면서 대를 이어 영구 정 착하는 것과 같다.

극심한 시장 경쟁을 벌이는 기업들에게 브랜딩은 기업 생 존이 걸린 핵심 경영 전략 중의 하나임은 이미 잘 알려진 사실이다(장 노엘 캐퍼러, 2009). 앞서 설명하였듯 어느 한 $\mathrm{UX}$ 생태계에 정착한 고객은 고객 고착화에 의해 어지간해 서는 그 생태계를 벗어나려 하지 않는 성향을 갖게 된다. 이런 성향은 이를테면 어떤 한 고객 니즈(customer needs) 에 대해 여러 기업에서 비슷한 내용과 수준의 서비스를 경 쟁적으로 선보였을 때 고객은 자신이 안착한 생태계에 가장 준수(conform)하는 서비스를 자연스레 선택하게끔 유도한 다. 이는 브랜드 분야에서 누누이 강조하는 소비자는 자신 이 익숙한 브랜드만을 습관적으로 고른다는 원리와 일맥상 통한다.

\section{5. 애플의 3-4단계 UX 표준화의 사례}

잘 알려진 대로 애플은 이미 80년대에 $\mathrm{GUI}$ 를 성공적으 로 상업화 시킨 저력을 가진 UX의 최강자이다. IT 하드웨어 제조, 소프트웨어 기술 및 UX에 대한 30년 가까이 쌓은 저 력을 토대로 애플은 지난 10년간 iPod, iPhone, iPad, 앱스 토어(App Store) 등 성공작을 연이어 내놓으면서 착실하게 애플만의 고유한 UX 생태계를 구축해 가고 있다.

애플은 UX 생태계 이전의 3단계 표준화에서도 다른 기 업들에 비해 월등히 앞서 있다. 가장 대표적인 예는 애플 iPod의 디지털 음악 경험(Digital Music Experience)이다. 경쟁자들이 MP3 플레이어 자체에만 공을 들이는 동안 애 플은 iPod와 iTunes를 중심으로 심리스하고 통합적인 디지 털 음악 경험의 체제를 구축하였다(그림 3 ).



그림 3. Apple의 Digital Music Experience
이를테면 iPod를 컴퓨터에 연결하면 자동으로 음악 파일 관리 소프트웨어인 iTunes와 싱크가 된다. 또한 사용자는 바로 iTunes에서 동일명의 Apple 온라인 뮤직 스토어인 iTunes에 바로 들어가 음악 파일을 구매할 수 있다. 이름이 같을 정도로 이 두 iTunes의 통합성은 최고 수준이다. 음악 파일의 구매, 전송, 재생, 관리 등에 대한 일련의 UX가 이렇 게 통합적으로 잘 이루어진 디지털 음악 경험은 애플 이전에 존재하지 않았다. 제품, 소프트웨어, 컨텐츠 서비스가 완벽 하게 삼박자를 이룬 통합 UX를 기반으로 애플은 사용자의 궁극적이면서도 사실상 유일한 관심사인 "음악을 편하게 구 매하고 청취하는" 경험을 만들고자 노력을 했기에 MP3 플 레이어와 온라인 음반 판매 양쪽에서 모두 절대적 시장 지 배자로 자리잡을 수 있었다.

$\mathrm{iPod}$ 에서의 성공 경험은 iPhone으로 이어졌고 애플은 $\mathrm{iPod}$ 경험 시스템의 성공적인 노하우를 바탕으로 강력한 모바일 생태계(Strategy Analytics, 2008; 디지털데일리, 모바일 신천지 열린다 기사 참조)를 구축하였다. 개방화에 기반하여 SDK를 공개하고, 앱스토어를 통해 써드파티와 일 반 고객들이 적극적인 프로슈머로 참여할 수 있도록 하였으 며, 이익을 분배하는 비즈니스 모델을 통해 개발자들의 지속 적인 참여를 유도하는 win-win 시스템을 만들었다. 이런 과정에서 확고하게 다져진 애플의 고객 충성도는 진가를 발 휘했다. iPhone 사용자들 iPhone보다 스펙상 더 뛰어난 스 마트폰들이 나와도 어지간해서는 애플 아이폰을 떠나 다른 환경으로 이주하는 일이 없게 되었고, 현재 스마트폰을 보 유하지 않은 소비자들도 줄을 서서 새로운 iPhone의 등장을 기대하는 강력한 잠재적 고객이 되었다.

2010년 1월에 애플은 iPhone에 이은 또 하나의 히트작 인 $\mathrm{iPad}$ 를 출시하였다. $\mathrm{iPad}$ 는 iPhone과 맥킨토시 컴퓨터 사이의 간격을 메워 주는 단말기이다. 또한 그동안 성공적인 평가를 못 받은 애플 $\mathrm{TV}$ 를 대폭적으로 업그레이드하여 스 마트 TV 시장에 뛰어들 것으로 예상된다(한영수, 2009; 지디넷 코리아, 2010년 6월 6일자 기사 참조). $\mathrm{iPad}$ 나 새 로운 Apple TV는 모두 iPhone과 동일한 운영체제 iOS4 를 사용함으로써 iOS4의 인터랙션 경험을 제품간에 동일하 게 제공하게 될 것이다.

애플의 이러한 UX 전략적 행보는 그들이 현재 구축해둔 강력한 모바일 생태계를 N-Screen 시장으로 확장하여 $\mathrm{N}-\mathrm{Screen}$ 을 기반으로 한 강력한 UX 생태계를 구축하려 는 의지를 잘 보여준다. 애플이 iTunes을 통해 쌓아둔 강 력한 미디어 컨텐츠 서비스의 명성을 토대로 iPod, iPhone, $\mathrm{iPad}$, 그리고 조만간 나올 $\mathrm{TV}$ 제품을 통해 본격적으로 $\mathrm{N}-\mathrm{Screen}$ 시장에 뛰어들 것은 자명한 일이다(조연아 등, 2010). Apple TV와 함께 예측되는 애플의 또 하나의 행보 로 애플이 현재 제공하는 개인 정보 클라우드 컴퓨팅 서비스 
인 MobileMe를 iTunes와 같은 컨텐츠 서비스와 통합하여 클라우드 기반의 강력한 N-Screen 서비스를 구축하는 것 이다(아틀라스 리서치, 2010). 이런 행보를 통해 그림 4에 나와 있듯 애플은 고객을 그들의 스크린으로 둘러싸고 애플 의 iTunes, App Store 및 iBooks에서의 컨텐츠 판매를 극 대화 할 것이다. 애플 고객은 애플이 조성한 $\mathrm{N}-\mathrm{Screen}$ 환 경 속에 거주하면서 충성 고객이 되는 것이다.

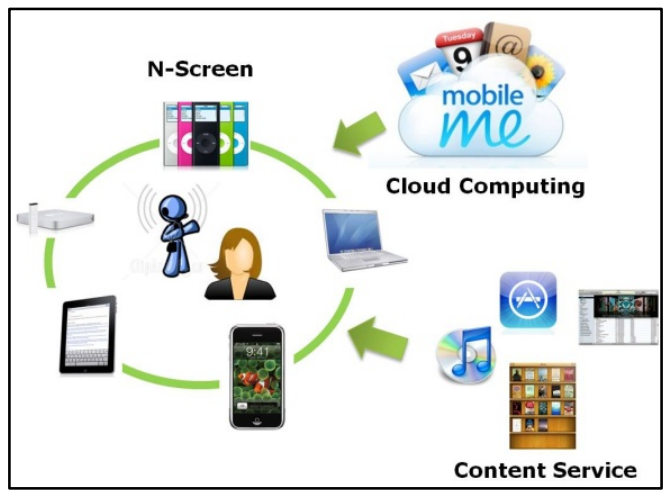

그림 4. N-Screen에서의 Apple의 행보

맥킨토시 - iPod - iPhone - iPad - TV 및 iTunes (SW) - iTunes (온라인 스토어)에서 애플이 기구축한 1 3 단계의 UX 표준화, 앱스토어를 중심으로 한 모바일 생태 계, N-Screen 생태계로의 진화, 강력한 클라우드 컴퓨팅 기반의 N-Screen 환경 구축을 통해 애플의 모든 UX가 심리스하게 통합될 때 애플은 전세계적으로 가장 빨리 4 단 계 표준화인 지속가능한 UX 생태계를 구축하게 될 것으로 예측된다.

\section{6. 글로벌 IT 패러다임의 변화와 지속가능한 UX 생태계의 연관성}

지속가능한 UX 생태계는 앞서 소개한 글로벌 IT 패러다 임의 변화와 호흡을 같이 한다. 이는 글로벌 IT 패러다임 속 에서 지속가능한 UX 생태계가 UX 디자인이 취해야 할 다 음 방향임을 잘 보여준다.

\section{1 커넥티드 디바이스, M2M, 이머징 디바이스}

네트워크로 연결되지 않는 제품/서비스군에서도 구축이 가 능한 표준화 1 3단계에 비해 UX 표준화의 4단계인 생태 계는 만족할 만한 수준의 항시연결(always connected)이
보장되는 네트워크 환경에서의 서비스들에서 논의가 가능 한 단계이다. 이를테면 클라우드 컴퓨팅 기반의 N-Screen 은 필수적으로 네트워크로의 항시연결성을 전제한다. 이는 진정한 모바일 인터넷 환경, 커넥티드 디바이스(connected device) 시대와 M2M으로 대변되는 이머징 디바이스 (emerging device)과 같은 새로운 IT 패러다임이 4단계 표준화의 개념을 탄생시킨 한 가지 배경이 되었음을 시사 한다.

\subsection{IT 개방화와 적극적 주체로서의 사용자}

Web 2.0에서부터 비롯된 개방화는 최근 앱스토어를 중심 으로 한 모바일 생태계에서 볼 수 있듯 IT계의 새로운 가치 를 만들어낸 패러다임이다. 개방화는 단순 소비자를 적극적 주체로서의 프로슈머로 탈바꿈 해주었으며 거주자로서의 고 객과 생태계 요소가 공생적인 관계를 이루어 상호 발전할 수 있는 기틀을 마련해 주었다. 애플의 사례에서 볼 수 있 듯 수익분배구조라는 Win-Win 시스템을 통해 수많은 써 드파티 업체들과 개인 개발자들이 다양한 앱을 생산하고 있 고 이는 다시 애플의 생태계를 풍부(enrich)하게 해주는 것으로 선순환 된다.

적극적 주체로서의 사용자는 UX 생태계에서 거주자 행동 양상과 일맥상통한다. "거주자" 개념은 고객을 단순히 소비 만 하는 사용자로부터 생태계를 돌리는 원동력의 한 주체로 승화시킨다. 이는 SNS의 활성화나 Web 2.0에서 말하는 집 단 지성을 더욱 강화시키는 강력한 배경이 된다. 생물이 생 태계에 정착한다는 것은 그 환경에 있는 자원을 단순히 소 비하는 개체가 아니라 다른 생물이나 환경 요소와 같은 생 태계 안의 구성 요소들과 공생하며 생명 활동을 영구적으로 - 즉, 대를 이어 - 하는 것을 의미한다. 마찬가지로 거주 자로서의 고객은 자신이 속한 UX 생태계의 운영, 유지 및 발전에 참여하는 적극적 주체이다.

프로슈머(prosumer), 협업 디자인(co-design, participatory design), 집단 지성 (collective intelligence), 바이럴 마케팅 (viral marketing), SN (Social Networking) 은 모두 UX 생태계 구성원으로서의 고객들의 적극적인 참 여와 활동의 가치를 잘 보여준다. UX 생태계의 구축에 따른 고객의 거주화는 이러한 "생태계 구성원으로서의 적극적 활 동 주체"라는 정체성 (identity)을 시스템적으로 정립하는 것 이 된다.

\section{3 클라우드 컴퓨팅}

클라우드 컴퓨팅은 UX 생태계 구축에 필수적인 IT 인프 라이다. 클라우드 컴퓨팅은 인터넷을 통한 가상화와 SaaS 
(Software as a Service)를 통해 접속만 되면 사용자가 언 제 어디서든 동일한 서비스를 받을 수 있게끔 해준다. 이를 테면 모든 주소록 정보를 서버 측에 두고 각기 다른 통신 서비스가 주소록의 실시간 업데이트를 공유함으로써 사용자 는 언제 어디서 어떤 통신 디바이스를 사용하든 동일한 주 소록을 가지고 통신할 수 있다. 이런 것은 UX 생태계에서 추구하는 정보 공유의 대표적 사례이다.

UX 생태계 안에서 제공되는 다양한 서비스들이 심리스 (seamless)하고 통합(unified) 적으로 상호 연계되기 위해서 는 클라우드 컴퓨팅의 환경이 선구축 되어야 한다. 안드로이 드(Andriod)라는 강력한 플랫폼을 앞세워 애플과 함께 새 로운 IT 패러다임에서 지속가능한 UX 생태계를 실제화 해 가고 있는 구글이 클라우드 컴퓨팅 환경의 리더인 점은 우 연이 아니다.

\section{$6.4 \mathrm{~N}-$ Screen}

$\mathrm{N}$-Screen은 화면을 가진 여러 개의 기기를 통해 동일한 컨텐츠와 서비스를 사용하는 환경이다(김윤화, 2009). 이를 테면 휴대폰, IPTV 및 일반 컴퓨터에서 동일한 영화 서비스 가 제공되는 것인데, 사용자는 자신의 환경에 맞게 어느 기 기로든 영화를 볼 수 있고 또 집으로 돌아오면서 휴대폰으 로 보던 영화를 집에 도착한 후에는 TV 화면을 통해 이어 서 볼 수도 있게 해주는 새로운 형태의 컨텐츠 서비스를 가 능하게 해준다. AT\&T에서 3-Screen(AT\&T weblink 참 조)이란 개념으로 시작한 N-Screen은 최근 클라우드 컴퓨 팅 인프라에 힘입어 더욱 강력한 서비스를 제공할 수 있게 되었다.

최근의 N-Screen에서는 이미 4단계 표준화를 요구한다. 이는 N-Screen이 앱스토어를 중심으로 한 모바일 생태계 를 N-Screen 생태계로 확장하려는 점에서 파악할 수 있 는데 이를테면 몇 년 전부터 시장에 나오기 시작한 인터넷 TV는 초기 빌트인 위젯(built-in widget) 형태에서 이제 앱스토어 기반의 스마트 TV로 진화하였다(연합뉴스, 2010 년 5월 21일자 기사 참조). 휴대폰이 N-Screen의 주요 구성원인 만큼 현재의 모바일 생태계는 N-Screen 생태계 의 일부로 합병될 것이다. 이에 따라 모바일 생태계에서 그 러하였듯 N-Screen의 생태계에서도 4 단계 표준화인 지속 가능한 UX 생태계의 구축이 필요해질 것이다.

\section{7. 표준화 4단계 및 지속가능한 UX 생태계 구축을 위한 디자인 전개 방법}

본 연구에서는 IT 패러다임의 변화에 따라 UX 디자인에 서의 개념과 전개 방법이 지금과는 달라져야 한다고 역설하 였다. 이를테면 3장에서 언급하였듯 지속가능한 UX 생태계 에서는 "사용자"를 "거주자"로 "사용하다"를 "거주하다"로 관점을 바꿔야 함을 설명하였다.

현재 대부분의 기업은 1,2 단계 UX 표준화에 머물러 있 다. 앞으로 표준화 3단계 및 최상위 단계인 UX 생태계로 진화하는 과정에서 기존의 표준화 작업 대비 고려해야 할 새 로운 디자인 개념은 아래와 같다. 특히 N-Screen과 같이 서로 다른 단말기들에서 동질의 컨텐츠와 서비스 경험을 제공하기 위해서는 이들을 명확하게 이해해야 한다(김성우, 2010).

- Different UI, Same UX

- Coherence $>$ Consistency

"Different UI, Same UX"는 여러 상이한 단말기들이 모 인 UX 생태계에서 각 단말기의 UI는 그 단말기의 고유 특 성에 맞게 지역최적화(local optimization) 하되 전체적으로 는 동질의 UX를 제공해야 한다는 디자인 방향이다.

Coherence와 consistency는 한국어로는 둘 다 일관성 이지만 coherence에는 "all the parts or ideas fit together so that they form a united whole"이란 점에서 획일적으로 똑같게 맞추는 consistency와는 다른 개념의 일관성이다. Coherence는 마치 소설의 기승전결이 각각의 내용은 다르 지만 전체적으로 볼 때 하나의 일관적인 스토리텔링을 하는 것과 같이 각각 다른 역할을 하는 단말기/서비스가 전체적으 로는 하나의 고도화된 경험을 제공할 수 있도록 서로 심리스 (seamless)하게 통합(unified) 되어야 하는 것을 의미하는 디자인 개념이다. 이를테면 각각 독립적인 서비스 $\mathrm{A}, \mathrm{B}, \mathrm{C}, \mathrm{D}$ 에서 거주자가 $\mathrm{A} \sim \mathrm{D}$ 를 혼합 사용하여 어떤 태스크를 완수 하고자 할 때 $\mathrm{A} \sim \mathrm{D}$ 간에 서로 원활하게 상호협업(co-op) 하여 전체적으로는 하나의 경험을 제공함으로써 거주자 입 장에서는 모두 동일한 브랜드라고 느끼게 해야 한다. 이런 원활한 협업은 우연으로 이루어지는 것이 아니라 서비스 $\mathrm{UX}$ 디자인 단계에서 세심하게 기획되어야 한다.

이 두 개념은 서로 밀접한 관계를 가진다. 이를테면 Same UX는 "globally coherent UX"를 의미한다. 또한 두 개념 모두 1,2 단계만 생각한 표준화에서 종종 발생하는 부작용 인 "획일적 규격화"를 3단계 이상의 표준화에서는 적절하게 방지한다는 점에서도 일맥상통하다. "획일적 규격화"란 많 은 기업이 1,2 단계 표준화에서 $\mathrm{UI}$ 의 일관성을 너무 강조한 
나머지 똑같은 UI를 서로 다른 고유성을 가진 제품/서비스 에 강제로 적용하면서 하향 평준화 되어 $\mathrm{UX}$ 의 품질을 떨어 뜨리는 것을 의미한다.

앞서도 언급하였듯 N-Screen 생태계에서는 이 2가지 디자인 개념이 특히 중요하다. N-Screen에서는 서로 다 른 단말기와 서비스가 한 환경 속에서 공존한다. 이런 환 경 속에서의 UX 표준화를 1,2 단계에서 하던 "똑같이 맞 추는 것"으로 해서는 안 된다. 각각의 고유한 특성을 살리 는 different UI를 제공하되 전체적으로 심리스하게 통합된 same UX가 되어야 하며, 여러 단말기/서비스가 공존하며 원활하게 상호 협업하는 생태계에서는 마치 소설의 기승전 결 단계가 전체적으로 하나의 일관된 스토리를 독자에게 전 달하기 위해 존재하는 것처럼 global coherence를 가져야 한다.

\section{8. 결론 및 앞으로의 연구 방향}

본 논문은 현재 급격하게 진행 중인 글로벌 IT 패러다임 의 변화(paradigm shift)에서 UX가 나아가야 할 디자인 방 향을 기업의 브랜드 파워 강화에 기여하는 UX 표준화 관점 에서 다루었다. 본 연구는 먼저 UX 표준화 4 단계 모델을 소개하였고 이어 현재의 IT 패러다임 변화 속에서 UX 디 자인의 차세대 방향은 4 단계 표준인 지속가능한 UX 생태계 (sustainable UX ecosystem)의 구축이 되어야 함을 역설 하였다. 애플의 UX 전략에 대한 리뷰를 통해 생태계 구축의 실제 사례를 살펴보았고 지속가능한 UX 생태계가 글로벌 IT 패러다임과 어떤 연결성을 가지는지 규명하여 IT에서의 차세대 UX 방향이 지속가능한 UX 생태계임을 설명하였다. 마지막으로 지속가능한 UX 생태계 구축에 필요한 UX 디 자인 방향에 대해 기술하였다.

앞으로 본 연구는 본론에 소개된 UX 표준화 4 단계 중 3 단계와 4 단계 표준화에 맞춰 다음과 같은 연구 사안에 중 점을 두어 수행될 것이다. 이 중에서도 특히 두 번째 사안에 초점을 맞출 예정이다.

1. 1 2단계와 명확하게 구별되는 3 단계 경험 표준화에 해당하는 핵심 UX 요소들을 찾아 나열. 이를 바탕으로 인 터랙션 경험(interaction experience) 이상의 UX에 대한 정의와 범주를 규정

2. 4단계 생태계 표준화에 해당하는 핵심 UX 요소들을 찾아 나열하고 지속가능한 UX 생태계 구축에 필요한 구체 적인 디자인 전개(deployment) 방법: 지속가능한 UX 생태 계 구축에 필요한 디자인 가이드라인 및 생태계의 운영/유
지/발전을 위한 UX 디자인 경영 (UX design management) 방법 제안

\section{참고 문헌}

Cusumano, M., "Cloud Computing and SaaS as New Computing Paradigm", Communications of ACM, Vol.53, April 2010.

Marcus, A., "Branding 101", ACM Interactions pp14-21, September/ October, 2004.

Meyer, C. and Schwager, A., "Understanding Customer Experience", Harvard Business Review, February 2007.

Pierece, J. and Roedl, D., "Changing Energy Use Through Design", ACM Interactions, July /August 2008.

Shaw, C. and Ivens. J., Building Great Customer Experiences, Palgrave Macmillan (November 25, 2004).

Sampson, F., "Pushing the Envelope", ACM Interactions, July/August, 2005.

Towards a Shared Definition of User Experience, CHI 2008 Special Interest Group, Florence, Italy, 2008.

김윤화, 3 스크린 플레이 (3 Screen Play) 서비스 추진 현황, 방송통 진정책 제 21 권 11 호 통권 464호, 2009.

김성우, 김준환, 이동석, 이지현, "스마트폰 돌풍의 주역, UX 패러 다임의 변화와 대응전략", KT 경제경영연구소 디지에코 오픈 세미나, 2010.3.10.

아틀라스 리서치 (Atlas Research), N-Screen 전략 비교: MS, 애플, 구글, 2010 .

장 노엘 캐퍼러, 뉴패러다임 브랜드 매니지먼트, 김앤김북스, 2009. 정경원, 디자인경영, 안그라픽스, 2006.

조연아, 정영조, 최윤정, "iPad가 가져오는 변화와 의미", KT 경제 경영연구소 디지에코, 2010.4.

조기원, 디자인전략, 미래사, 2007.

한영수, "애플이 TV 산업에 진입한다면", LG Business Insight, 2009 년 12월 9일.

Strategy Analytics, "Understanding the Mobile Ecosystem", January 2008.

AT\&T, Three Screens, http:/www.att.com/Common/files/pdf/ AT\&T-3_ScreensFactSheet_0530.pdf

Oreilly, Web 2.0, http://oreilly.com/web2/archive/what-is-web-20.html SONY XMB, http://en.wikipedia.org/wiki/XrossMediaBar

디지털데일리, 모바일 신천지 열린다, http://www.ddaily.co.kr/news/ news_view.php?uid $=57572$

연합뉴스, 2010년 5월 21일, 구글 TV, 스마트 TV 시대 본격화 예고, http://www.yonhapnews.co.kr/economy/2010/05/21/0302000000AK R20100521047900017.HTML

전자신문 2005년 4월 25일, SKT 휴대폰 UI 업그레이드, http:// www.etnews.co.kr/news/detail.html?id=200504240021

지디넷 코리아, 2010년 6월 6일, 99달러짜리 차세대 애플 TV 등장 초읽기, $\quad \mathrm{http} / /$ www.zdnet.co.kr/ArticleView.asp?artice_id $=20100529073029$ 


\section{저자 소개}

김 성 우 caerang@gmail.com

MS, Information Design \& Technology, Georgia Tech

현 재: $\mathrm{KT}$ 종합기술원 중앙연구소 책임연구원

관심분야: User Experienc
논 문 접 수 일 (Date Received) : 2010년 07월 06일 논 문 수 정 일 (Date Revised) :2010년 07월 19일 논문게재승인일 (Date Accepted) : 2010년 07월 19일 